\title{
Inducible Nitric Oxide Synthase Expression in Chronic Viral Hepatitis Evidence for a Virus-induced Gene Upregulation
}

\author{
Pedro L. Majano, ${ }^{\star}$ Carmelo García-Monzón, ${ }^{\star}$ Manuel López-Cabrera, ${ }^{\ddagger}$ Enrique Lara-Pezzi, ${ }^{\ddagger}$ Elena Fernández-Ruiz, ${ }^{\ddagger}$ \\ Consuelo García-Iglesias, ${ }^{*}$ María J. Borque, ${ }^{\ddagger}$ and Ricardo Moreno-Otero* \\ * Liver Unit and ${ }^{\ddagger}$ Molecular Biology Unit, Hospital de la Princesa, Universidad Autónoma de Madrid, 28006 Madrid, Spain
}

\begin{abstract}
Increased nitric oxide (NO) production may contribute to the pathological changes featuring in some inflammatory diseases, but the role of NO in chronic viral hepatitis is still unknown. We compared the inducible NO synthase (NOS2) expression in the liver of patients with chronic viral hepatitis with that of both nonviral liver disease and histologically normal liver. NOS2 expression was assessed by immunohistochemical and in situ hybridization studies of liver biopsy sections. An intense hepatocellular NOS2 reactivity was detected in chronic viral hepatitis, whereas it was weakly or not observed in nonviral liver disease or normal liver, respectively. In addition, we determined whether the hepatitis $B$ virus (HBV) might regulate the synthesis of this enzyme. NOS2 mRNA and protein levels as well as enzyme activity were assessed in cytokine-stimulated HBV-transfected and untransfected hepatoma cells. Transfection with either HBV genome or HBV X gene resulted in induction of NOS2 mRNA expression, and the maximal induction of this transcript and NO production was observed in cytokine-stimulated HBV-transfected cells. These results indicate that hepatotropic viral infections are able to upregulate the NOS2 gene expression in human hepatocytes, suggesting that NO may mediate important pathogenic events in the course of chronic viral hepatitis. (J. Clin. Invest. 1998. 101: 1343-1352.) Key words: nitric oxide • nitric oxide synthase • hepatitis $\mathrm{B}$ virus - hepatitis $\mathrm{C}$ virus - hepatocellular carcinoma
\end{abstract}

\section{Introduction}

Nitric oxide $(\mathrm{NO})^{1}$ is a highly reactive gaseous molecule produced by a wide variety of eukaryotic cells, from the guanidino nitrogen of L-arginine, by the action of the enzyme NO synthase (NOS) (1-3). There are two isoforms of constitutive NOS which are expressed in neurons (NOS1) and endothelial cells (NOS3), generating small amounts of NO $(4,5)$. The inducible isoform (NOS2) can be expressed de novo by many

Address correspondence to Dr. Carmelo García-Monzón, Unidad de Hepatología (planta 3), Hospital de la Princesa, C/ Diego de León, 62, 28006 Madrid, Spain. Phone: 341-309-3911; FAX: 341-401-3582; E-mail: garciamonzon@hotmail.com

Received for publication 30 May 1997 and accepted in revised form 2 February 1998

J. Clin. Invest.

(C) The American Society for Clinical Investigation, Inc. 0021-9738/98/04/1343/10 \$2.00

Volume 101, Number 7, April 1998, 1343-1352

http://www.jci.org cell types, including macrophages (6) and hepatocytes (7), after induction with bacterial endotoxin and proinflammatory cytokines $(8,9)$, thus producing large quantities of NO.

NO has been implicated as a mediator of immune and inflammatory responses (10). Increased tissue NOS2 expression and NO production have been observed in distinct animal models, such as in the brain of mice with experimental autoimmune encephalomyelitis (11) and in kidneys from a murine lupus model (12). More recently, different authors have reported that increased NOS2 expression and NO generation may contribute to the pathological changes featuring in rheumatoid arthritis (13-15) and Alzheimer's disease (16).

Chronic viral hepatitis $(\mathrm{CVH})$ is characterized by a parenchymal infiltration of activated cytotoxic $\mathrm{T}$ lymphocytes, regarded as the main cause of hepatic injury (17). Moreover, the existence of an intrahepatic upregulatory process involving adhesion molecules, such as intercellular adhesion molecule 1 and vascular cell adhesion molecule $1(18,19)$, and certain proinflammatory cytokines, such as TNF- $\alpha$ (20) and IFN- $\gamma$ (21), has been well documented. Interestingly, Geller et al. (22) demonstrated that proinflammatory cytokines play a central role in the hepatocellular NOS2 upregulation, inducing NO production in human hepatocytes. To examine the potential role of NO in the pathogenesis of liver disease caused by $\mathrm{HBV}$ and $\mathrm{HCV}$, we assessed the NOS2 expression pattern in the liver tissue from patients with $\mathrm{CVH}$, searching for correlations between the expression level of this enzyme and the histological inflammatory activity of liver disease. In addition, due to the fact that $\mathrm{HBV}$, through its transactivator protein $\mathrm{X}$ $(\mathrm{HBx})$, is capable of upregulating different cellular genes (23, 24), we investigated whether HBV could upregulate the NOS2 gene expression in cultured hepatocyte-derived cells.

\section{Methods}

\section{Patients}

The study included $44 \mathrm{CVH}$ patients with liver biopsy findings compatible, according to internationally accepted criteria (25), with chronic active hepatitis (CAH). CAH type B (CAHB) was diagnosed in 15 patients, and CAH type $\mathrm{C}$ (CAHC) in 29. The diagnostic criteria for viral hepatitis included persistent elevation of serum alaninoaminotransferase levels and either the positivity of both hepatitis B surface antigen (HBsAg) and HBV DNA in the serum of patients with CAHB, or the presence of both antibodies to HCV (anti-HCV) and HCV RNA in the serum of patients with CAHC, $>6$ mo before

1. Abbreviations used in this paper: $\mathrm{CAH}$, chronic active hepatitis; $\mathrm{CM}$, cytokine mixture plus LPS; $\mathrm{CVH}$, chronic viral hepatitis; G3PDH, glyceraldehyde 3-phosphate dehydrogenase; HBsAg, hepatitis B surface antigen; $\mathrm{HBV}$, hepatitis B virus; $\mathrm{HBx}, \mathrm{HBV}$ protein $\mathrm{X}$; HCC, hepatocellular carcinoma; $\mathrm{HCV}$, hepatitis $\mathrm{C}$ virus; $\mathrm{HI}$, hepatitic index; NO, nitric oxide; NOS, nitric oxide synthase; RT, reverse transcription. 
undergoing liver biopsy. Liver tissues from 12 alcoholic patients (8 with histological features of steatosis, and 4 with cirrhosis), 14 patients with histological changes of cholestasis (mild portal inflammation and/or ductular hyperplasia), and 8 patients with histologically normal liver were also studied as controls for immunohistochemical and in situ hybridization analysis. Patients with alcoholism included in this study consumed $>80 \mathrm{~g} / \mathrm{d}$ of ethanol for $>10 \mathrm{yr}$, and a percutaneous liver biopsy was performed on each one for diagnostic purposes. Liver biopsy samples with histopathological features of cholestasis or with nonspecific histological reactive changes (normal liver) were obtained during abdominal surgery for noncomplicated cholelithiasis. All of these control patients were negative for $\mathrm{HBsAg}$ and anti-HCV, and both $\mathrm{CVH}$ and control patients lacked antibodies to HIV (anti-HIV). Finally, samples from 10 of 44 patients with $\mathrm{CVH}$ included in this study ( 4 with CAHB and 6 with CAHC), 3 of 12 patients with alcoholic liver disease (steatosis), 4 of 14 patients with cholestasis, and 4 of 8 cases with histologically normal liver were randomly chosen for in situ hybridization analysis.

\section{Viral markers}

HBsAg and anti-HIV were determined by commercially available enzyme immunoassay kits (Abbott Laboratories, North Chicago, IL). HBV DNA was tested by a commercial immunoassay kit (Hybrid Capture system; Murex Diagnosticos S.A., Madrid, Spain). Anti$\mathrm{HCV}$ was detected using a commercially available second-generation enzyme-linked immunoassay kit (Ortho Diagnostic Systems, Inc., Raritan, NJ). HCV RNA was detected by a nested PCR technique using primers from the highly conserved $5^{\prime}$ noncoding region of the HCV genome, as described elsewhere (26).

\section{Liver tissue studies}

Liver biopsy samples from $\mathrm{CVH}$ and alcoholic patients were obtained, after informed written consent, using a Menghini needle by a percutaneous route. Liver samples from patients with histopathological features of cholestasis or nonspecific histological reactive changes were obtained, after informed written consent, during laparotomy for noncomplicated cholecystectomy.

Liver histology. Liver biopsy specimens were evaluated by the same pathologist, recording the conventional histological diagnoses and, in the biopsy sections from patients with virus-induced chronic liver disease, the histological activity index, subscored for hepatitic index (HI; portal, periportal, and lobular inflammation) and fibrotic index, described by Knodell et al. (27).

Immunohistochemical analysis. Cryostat liver sections were incubated with an $\mathrm{IgG} 2 \mathrm{a} \mathrm{mAb}$ that recognizes a $21-\mathrm{kD}$ protein fragment corresponding to amino acids 961-1144 of mouse macrophage NOS2 (Transduction Laboratories, Lexington, KY) at a working concentration of $1 \mu \mathrm{g} / \mathrm{ml}$. Given that this anti-NOS2 mAb cross-reacts with the neuronal constitutive isoform of NOS (NOS1) (28), we used a polyclonal anti-human NOS1 antibody which recognizes a $22.3-\mathrm{kD}$ protein fragment corresponding to amino acids 1095-1289 of human NOS1 (Transduction Laboratories) at a working concentration of 1 $\mu \mathrm{g} / \mathrm{ml}$ as an internal control in all immunostaining experiments. Furthermore, all tissue sections were also incubated with the TEA 3/1 (IgG2a) anti-E-selectin mAb (19) and a rabbit anti-mouse antiserum (Dakopatts A/S, Copenhagen, Denmark), both at a working concentration of $1 \mu \mathrm{g} / \mathrm{ml}$, and were used as negative controls. Finally, each section was evaluated semiquantitatively under code as detailed elsewhere (18).

RNA probes. A 700-bp SphI-BamHI cDNA fragment of human hepatocyte NOS2 (kindly provided by Dr. David A. Geller, Department of Surgery, University of Pittsburgh) cloned into pGEM-3Z (Promega Corp., Madison, WI) was used as a template to generate digoxigenin-labeled sense and antisense RNA probes, as described previously (29). A 550-bp fragment of the rat serum albumin cDNA was used as a positive control for hybridization on hepatocytes.

In situ hybridization technique. Paraffin-embedded liver sections were fixed in freshly prepared $4 \%$ paraformaldehyde for $20 \mathrm{~min}$, di- gested 12 min with $25 \mu \mathrm{g} / \mathrm{ml}$ proteinase $\mathrm{K}$ (Boehringer Mannheim, Mannheim, Germany), and hybridized overnight at $45^{\circ} \mathrm{C}$ with a preheated $\left(75^{\circ} \mathrm{C}, 5 \mathrm{~min}\right)$ hybridization mixture of $50 \%$ formamide, $5 \times$ SSC, $1 \mathrm{mM}$ EDTA, $250 \mu \mathrm{g} / \mathrm{ml}$ yeast tRNA, 0.1\% 3-[3-(holamidopropyl) dimethyl-ammonio]-1-propanesulfonate (CHAPS), and $2.5 \mu \mathrm{g} / \mathrm{ml}$ of digoxigenin-labeled RNA probe. After three posthybridization washings in $50 \%$ formamide, $2 \times \mathrm{SSC}$, and $0.1 \% \mathrm{CHAPS}$ at $50^{\circ} \mathrm{C}$, sections were treated once with $20 \mathrm{ng} / \mathrm{ml}$ ribonuclease A (Sigma Chemical Co., St. Louis, MO) in $2 \times \mathrm{SSC}$ at $37^{\circ} \mathrm{C}$ for $20 \mathrm{~min}$. After the same posthybridization washes, probe binding was visualized with an alkaline phosphatase-conjugated antidigoxigenin antibody (Boehringer Mannheim) diluted at 1:500, and color was achieved by adding a substrate solution as described previously (29). Finally, liver sections were counterstained with nuclear Fast Red (Sigma Chemical Co.) and mounted by standard methods.

\section{Cell culture and cytokine activation}

Human hepatoma HepG2 cells and the 2.2 .15 cell line, which is a stably transfected derivative of HepG2 cells developed by transfection with a dimerized HBV genome (30), were grown in phenol red-free DME (BioWhittaker, Inc., Walkersville, MD) supplemented with $5 \mu \mathrm{M}$ L-glutamine, gentamicin $(20 \mathrm{mg} / \mathrm{ml}), 10 \%$ heat-inactivated FCS, and $0.5 \mathrm{mM}$ L-arginine hydrochloride (Sigma Chemical Co.). Once cell culture dishes were subconfluent $\left(\sim 5 \times 10^{6}\right.$ cells $)$, the medium was changed, and cells were incubated with a mixture of $1 \mu \mathrm{g} / \mathrm{ml}$ of LPS (Escherichia coli 0111:B4; Sigma Chemical Co.), $250 \mathrm{U} / \mathrm{ml}$ human recombinant IL-1 $\beta$ (Genzyme Corp., Boston, MA), $250 \mathrm{U} / \mathrm{ml}$ human recombinant TNF- $\alpha$ (Genzyme Corp.), and $250 \mathrm{U} / \mathrm{ml}$ human recombinant IFN- $\gamma$ (Genzyme Corp.) for 6, 12, 24, and $48 \mathrm{~h}$.

\section{RNA isolation and Northern blot analysis}

Total RNA was extracted from cultured cells using the ULTRASPEC ${ }^{\circledR}$ RNA isolation system (Biotecx Laboratories, Houston, TX). Aliquots containing $15 \mu \mathrm{g}$ of RNA from each cell sample were run on $1 \%$ formaldehyde/agarose gels, transferred onto nitrocellulose membranes (Amersham International, Little Chalfont, Bucks, UK), and ultraviolet autocross-linked (UV Stratalinker 1800; Stratagene Inc., La Jolla, CA). Membranes were hybridized overnight at $42^{\circ} \mathrm{C}$ with a $2.1-\mathrm{kb}$ probe from the human hepatocyte NOS2 cDNA. The hybridized filters were washed at $60^{\circ} \mathrm{C}$, and autoradiography was performed at $-70^{\circ} \mathrm{C}$ in the presence of intensifying screens.

For dot blot hybridization experiments, the RNA samples were loaded onto the nitrocellulose membranes following the manufacturer's instructions for the Bio-Dot ${ }^{\circledR}$ SF microfiltration apparatus (Bio-Rad Laboratories, Richmond, CA), as described above. Dot blot membranes were washed and hybridized with a probe for glyceraldehyde 3-phosphate dehydrogenase (G3PDH), a constitutively expressed gene in these cells, to control for variations in the amount of total RNA per lane. Relative mRNA levels were quantitated by PhosphorImager scanning using ImageQuant software (Molecular Dynamics, Sunnyvale, CA).

\section{Western blot analysis}

Cells were resuspended in $100 \mathrm{mM} \mathrm{NaCl}, 10 \mathrm{mM}$ Tris- $\mathrm{HCl}$, pH 7.6, 1 $\mathrm{mM}$ EDTA, $0.1 \mathrm{mM}$ PMSF, $1 \mu \mathrm{g} / \mathrm{ml}$ aprotinin, and $5 \mu \mathrm{g} / \mathrm{ml}$ pepstatin $\mathrm{A}$, and an equal volume of $2 \times$ SDS loading buffer $(100 \mathrm{mM}$ Tris- $\mathrm{HCl}$, pH 6.8, 200 mM DTT, 4\% SDS, $0.02 \%$ bromophenol blue, $10 \%$ glycerol, $1 \% \beta$ mercaptoethanol) was added. The cytosolic fraction was obtained by centrifugation at $13,000 \mathrm{~g}$ for $20 \mathrm{~min}$ at $4^{\circ} \mathrm{C}$. Protein samples $(50 \mu \mathrm{g})$ were electrophoresed under reducing conditions on 7.5 or $10 \%$ SDS-PAGE gels, blotted onto nitrocellulose membranes (Amersham International), and probed with polyclonal anti-NOS2 antibody (Transduction Laboratories) at 1:500 or polyclonal antiactin antibody (Sigma Chemical Co.) at 1:1,000 followed by a goat anti-rabbit $\mathrm{IgG}$ conjugated with horseradish peroxidase (Pierce Chemical Co., Rockford, IL). Blots were developed by enhanced chemiluminescence (Amersham International). Cell lysates from the murine macrophage cell line RAW 264.7 provided by the manufacturer (Transduction Laboratories) were used as a positive control. 


\section{Nitrite measurements}

To determine the amount of NO produced by the HepG2 and 2.2.15 cell lines under the different cytokine-mediated activation conditions, the culture supernatants were tested for the stable end product, nitrite, using an automated procedure based on the Griess reaction (31).

\section{Plasmids}

The plasmid pHBV containing the entire HBV genome inserted in the EcoRI site of psP65 plasmid vector (Promega Corp.) was a gift from Dr. Aleem Siddiqui (University of Colorado Health Sciences Center, Denver, CO). The recombinant plasmids psV-X, psV-H, and psV- $\beta$ Gal were kindly provided by Dr. Massimo Levrero (I Clinica Medica and Fondazione Andrea Cesalpino, Policlinico Umberto I, Rome, Italy). They contain the complete HBV X, hygromicine, and $\beta$ galactosidase open reading frames, respectively, under the control of the SV40 enhancer/early promoter element.

\section{Cell lines, transfection, and PCR analysis}

The human hepatoma cell lines HepG2 and Hep3B, and the human nonneoplastic hepatocyte-derived cell line termed CCL13 obtained from the American Type Culture Collection (Rockville, MD) were used. HepG2 and CCL13 cells are negative for HBV DNA, whereas Hep3B cells express the HBsAg alone. Transient transfection of these cell lines, plated at a density of $3 \times 10^{5}$ cells, were performed in 30-mm dishes using the DOSPER liposomal transfection reagent (Boehringer Mannheim) according to the manufacturer's instructions. Briefly, cells were exposed to serum-free medium containing $5 \mu \mathrm{g}$ of plasmid DNA and $20 \mu \mathrm{g}$ of the liposome preparation for $6 \mathrm{~h}$, washed, and cultured in DME (BioWhittaker, Inc.) supplemented with $10 \%$ FCS for $36 \mathrm{~h}$. Total RNA $(0.5 \mu \mathrm{g})$ from transfected cells was reverse transcribed and amplified by PCR using specific primers for NOS2 and $\beta$-actin cDNAs and a Gene Amp RNA PCR core kit (Perkin-Elmer Corp., Norwalk, CT), as recommended by the manufacturer. The primers specific for NOS2 were 5'-TGCCAGATGGCAGCATCAGA-3' (sense) and 5'-ACTTCCTCCAGGATGTTGTA-3' (antisense) (Perkin-Elmer Corp.), and yielded a specific 370-bp PCR product. The primers specific for $\beta$-actin were $5^{\prime}$ ATCTGGCACCACCACCTTCTACAATGAGCTGCC-3' (sense) and 5'-CGTCATACTCCTGCTTGCTGATCCACATCTTGC-3' (antisense) (Clontech, Palo Alto, CA), and yielded a 838-bp product. The amplification reactions for NOS2 consisted of 25, 30, 35, and 40 cycles at $95^{\circ} \mathrm{C}$ for $1 \mathrm{~min}$, annealing at $50^{\circ} \mathrm{C}$ for $1 \mathrm{~min}$, and extension at $72^{\circ} \mathrm{C}$ for $30 \mathrm{~s}$. The amplification reactions for $\beta$-actin consisted of $15,20,25$, and 30 cycles at $95^{\circ} \mathrm{C}$ for $1 \mathrm{~min}$, annealing at $60^{\circ} \mathrm{C}$ for $1 \mathrm{~min}$, and extension at $72^{\circ} \mathrm{C}$ for $90 \mathrm{~s}$. The products were separated by agarose electrophoresis and visualized by ethidium bromide staining. The specificity of the amplified bands was validated by their predicted size. In addition, the 370-bp PCR product was sequenced (Amersham International) and found to be identical to that predicted from human hepatocyte NOS2 (7).

\section{Statistical analysis}

Data are presented as mean \pm SEM. The significance of differences was determined using the Mann-Whitney $U$ test for nonparametric data from immunohistochemical analysis and the Student's $t$ test for data from both NOS2 mRNA and nitrite levels. Statistical significance was established at a $P$ value $<0.05$.

\section{Results}

Intrahepatic NOS 2 expression pattern. We found a marked expression of NOS2 in liver sections from patients with both chronic HBV and HCV infections. NOS2 immunoreactivity was observed mainly in hepatocytes, showing a predominant cytoplasmic staining, with the positive liver cells distributed diffusely throughout the hepatic lobules and with a similar pattern in both types of CVH studied (Fig. 1, $A$ and $B$ ). In con- trast, a low level of NOS2 immunoreactivity was observed in hepatocytes from patients with both alcoholic steatosis and cholestasis (Fig. $1 \mathrm{C}$ ), restricted to some liver cells located mainly in perivenular and periportal areas. It was noticeable that in normal liver tissue, the expression of NOS2 was always negative (Fig. $1 D$ ). In addition, in all liver sections studied, no NOS2 staining was observed in liver-infiltrating mononuclear cells, vascular endothelium, or sinusoidal lining cells. Because the anti-mouse macrophage NOS $2 \mathrm{mAb}$ cross-reacts with the neuronal constitutive NOS (NOS1) (27), we carried out immunostaining experiments with a polyclonal anti-human NOS1 antibody. Interestingly, no NOS1 immunoreactivity was observed in any of the liver sections studied (Fig. $1 E$ ). This finding clearly indicates that the marked hepatocellular staining obtained with the anti-NOS $2 \mathrm{mAb}$ is due to a specific binding to the human hepatocyte NOS2. Using the TEA 3/1 mAb (Fig. $1 F$ ) and a rabbit anti-mouse antiserum as negative controls, no hepatic staining was obtained.

Searching for possible correlations between the hepatocellular NOS2 staining intensity and the inflammatory activity of $\mathrm{CVH}$, we first classified liver samples from these patients into two groups according to their hepatitic score (portal, periportal, and lobular inflammation) of the Knodell's index. Thus, five liver biopsies with $\mathrm{CAHB}$ and nine with CAHC had a low $\mathrm{HI}(<5)$, whereas the group with a high $\mathrm{HI}(>10)$ was comprised of six liver biopsies with CAHB and 14 with CAHC. We then carried out a comparative statistical analysis between the semiquantitative NOS2 staining score found in the mentioned groups of $\mathrm{CVH}$ and in alcoholic and cholestatic patients, whose data are shown in Table I. To summarize, no significant difference in the intrahepatic NOS2 distribution pattern and staining score between $\mathrm{CAHB}$ and $\mathrm{CAHC}$ was found, but this difference reached statistical significance compared with that obtained in the liver tissue from patients with alcoholic liver disease $(P<0.05)$ or cholestasis $(P<0.01)$.

In situ hybridization experiments using a specific antisense RNA probe showed the presence of high NOS2 mRNA levels in liver sections from both CAHB and CAHC. A strong expression of NOS2 mRNA was observed in hepatocytes (Fig. 2, $A$ and $B)$, with a pattern resembling that obtained in immunohistochemical studies. Some positive cells for NOS2 mRNA were also found in the mononuclear cell infiltrate and vascular endothelium (Fig. $2 \mathrm{C}$ ), a finding that contrasted with the absence of NOS2 immunoreactivity in these cells. In contrast, low levels of NOS2 mRNA were detected in liver sections

Table I. Comparative Immunohistochemical Scoring of NOS2 Expression

\begin{tabular}{lllll}
\hline & \multicolumn{3}{c}{ Low HI $(<5)$} & High HI $(>10)$ \\
\hline CAHB & $n=5$ & $2.2 \pm 1$ & $n=6$ & $2.6 \pm 0.8$ \\
CAHC & $n=9$ & $2.3 \pm 1$ & $n=14$ & $2.6 \pm 0.8$ \\
ALD & $n=9$ & $1.6 \pm 1^{*}$ & & \\
CHL & $n=10$ & $1.2 \pm 0.6^{* *}$ & &
\end{tabular}

Data are expressed as median values \pm SD. Scoring system: 0 , negative staining; 1 , focal and weak staining; 3 , diffuse and strong staining. $A L D$, Alcoholic liver disease. $C H L$, Cholestasis. ${ }^{*} P<0.05$ vs. both CAHB and CAHC. $* * P<0.01$ vs. both CAHB and CAHC. 

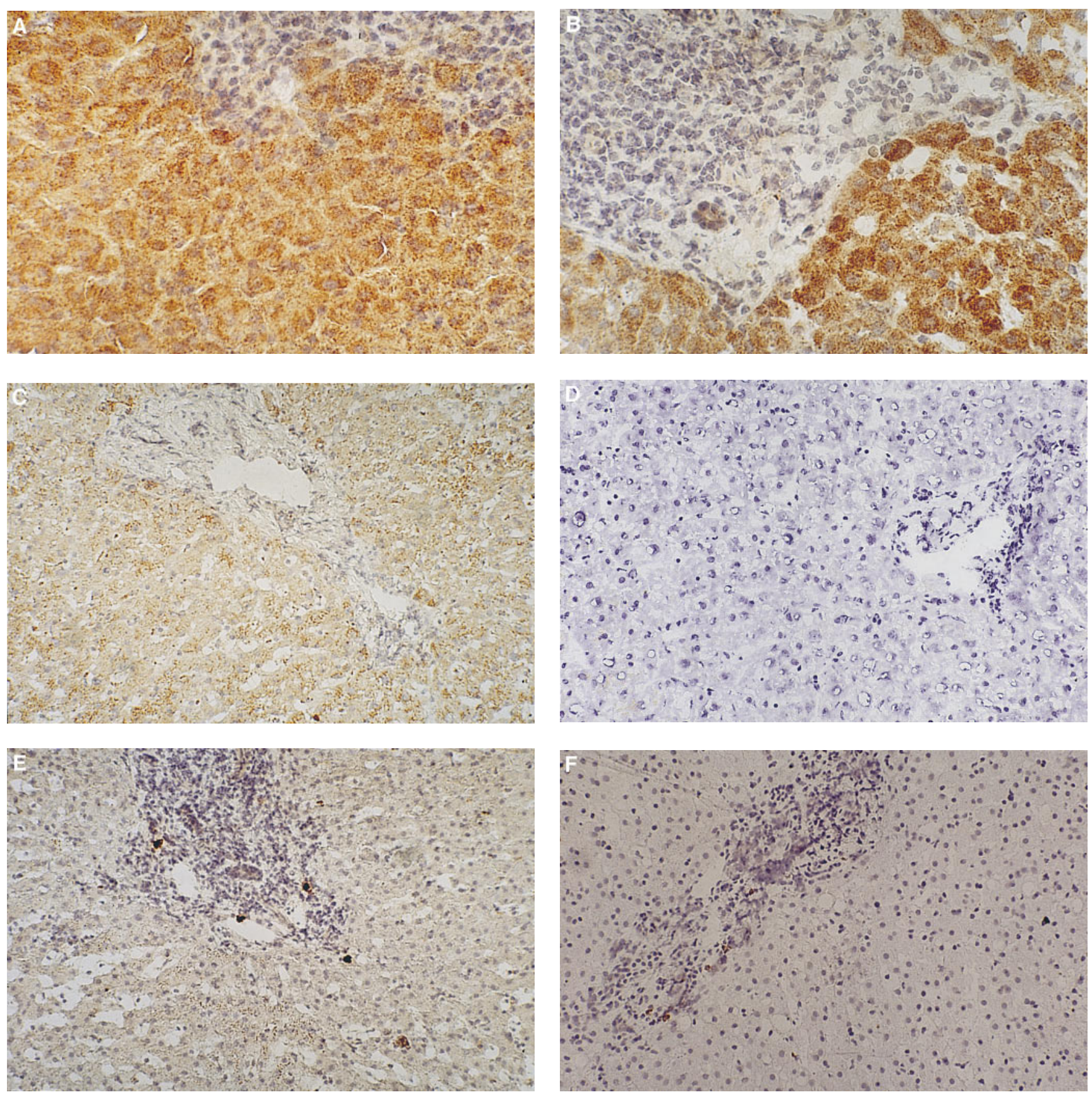

Figure 1. Immunohistochemical detection of NOS2 in liver sections. An intense immunoreactivity to NOS2 is shown in the liver tissue from a patient with chronic HBV with a low HI $(A$, original magnification $\times 500)$, and from a patient with chronic $\mathrm{HCV}$ with a low $\mathrm{HI}(B$, original magnification $\times 500)$. By contrast, a weak hepatocellular expression of NOS2 is observed in the liver sample from a patient with cholelithiasis-related cholestasis $(C$, original magnification $\times 300)$. Interestingly, no NOS2 expression is found in histologically normal liver $(D$, original magnification $\times 300)$. Noticeably, no NOS1 immunoreactivity is detected in hepatocytes from a patient with chronic $\mathrm{HBV}(E$, original magnification $\times 300)$. The negative control (IgG2a, TEA 3/1 anti-E-selectin $\mathrm{mAb}$ ) of immunoperoxidase staining is also shown $(F$, original magnification $\times 300)$.

from alcoholic steatosis (Fig. $2 D$ ) and cholestasis (Fig. 2 ). In these tissue samples, the NOS2 mRNA-expressing cells were also hepatocytes but were restricted to perivenular and periportal areas. It was interesting to note that no expression of NOS2 mRNA was found in histologically normal livers (Fig. 2 $F)$. Finally, in sections hybridized with sense NOS2 RNA probe, no positive signals were observed (data not shown).

$H B V$ induces NOS2 gene upregulation. Northern blot anal- ysis was performed to detect NOS2 mRNA expression in the human hepatoma cell line HepG2 and in the HepG2-derivative cell line stably transfected with the HBV genome termed 2.2.15, either with or without stimulation with LPS and a combination of TNF- $\alpha$, IL- $1 \beta$, and IFN- $\gamma$ (LPS plus cytokine mixture $[\mathrm{CM}]$ ). A single and specific transcript was detected at $\sim 4.5 \mathrm{~kb}$, the strongest band seen in CM-stimulated 2.2.15 cells (Fig. $3 A$, lane 4). To quantitate NOS2 mRNA levels, we car- 

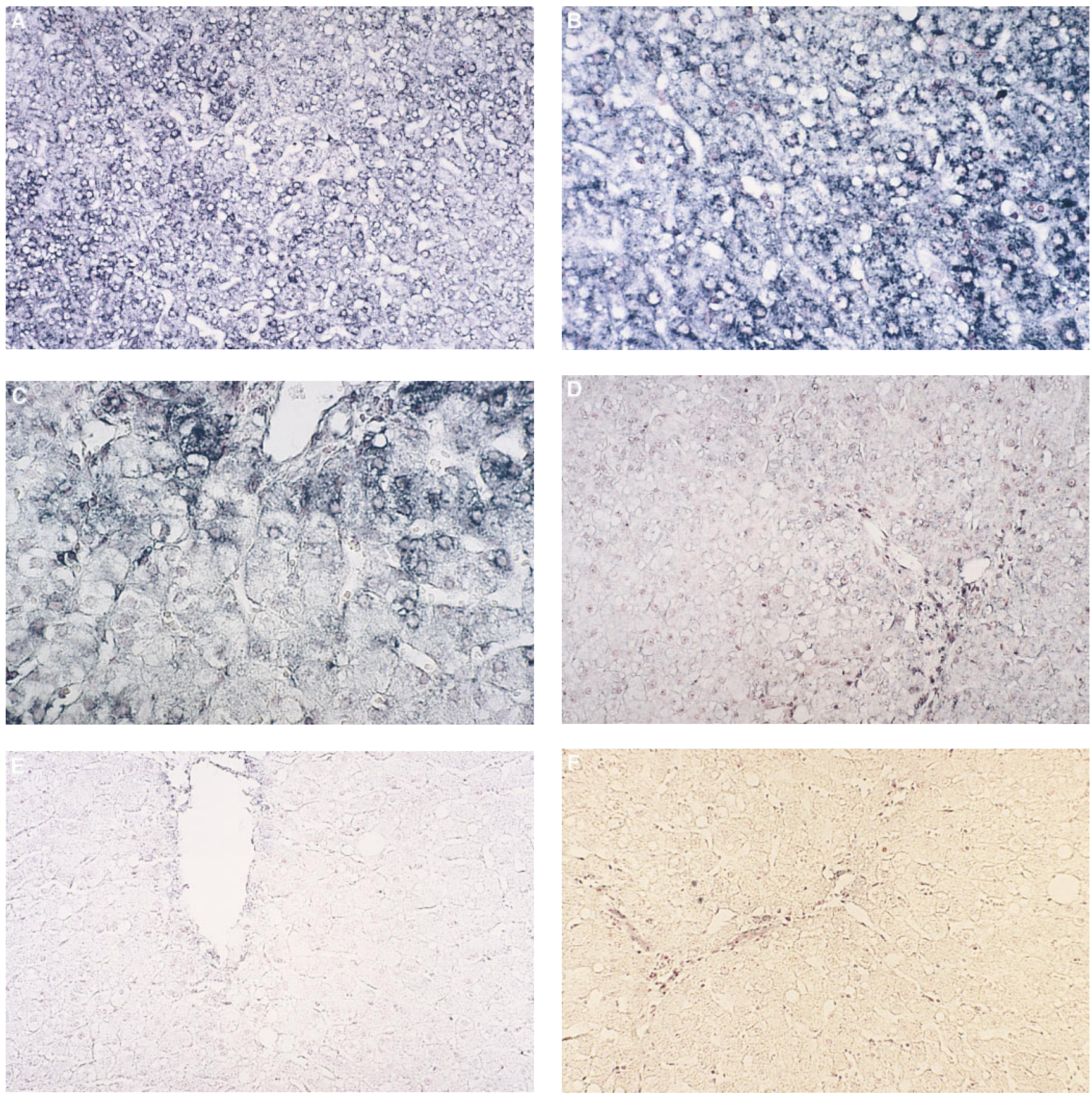

Figure 2. In situ detection of NOS2 mRNA using a nonradioactive antisense RNA probe. A marked expression of the NOS2 mRNA is shown in hepatocytes from a patient with chronic $\operatorname{HCV}(A$, original magnification $\times 300 ; B$, original magnification $\times 500)$. Positivity for NOS2 mRNA is also found in the central venous endothelium from the same patient $(C$, original magnification $\times 500)$. By contrast, only a few NOS2 mRNAexpressing hepatocytes are observed in the liver tissue from a patient with alcoholic steatosis $(D$, original magnification $\times 300)$, and from a patient with cholelithiasis-related cholestasis $(E$, original magnification $\times 300)$. In histologically normal liver, no NOS2 mRNA-expressing cells are detected $(F$, original magnification $\times 300)$.

ried out dot blot hybridization analysis using RNA samples under the same experimental conditions described above (Fig. $3 \mathrm{~B}$ ). In unstimulated (resting) HepG2 cells (lane 1), NOS2 mRNA was almost undetectable, but was induced after $12 \mathrm{~h}$ of $\mathrm{CM}$ stimulation (approximately threefold induction, $P<0.05$ vs. resting HepG2 cells) (lane 2). In contrast, resting 2.2.15 cells (lane 3) expressed higher (approximately fourfold, $P<$ 0.05) NOS2 mRNA levels than resting HepG2 cells and thus to a similar extent as CM-activated HepG2 cells. More interestingly, 2.2 .15 cells expressed still higher $(\sim 21$-fold induction, $P<0.01$ vs. resting HepG2 cells) NOS2 mRNA levels when stimulated with CM (lane 4). Subsequent probing for G3PDH RNA showed relatively equal loading of RNA samples.

To compare NOS2 protein levels with NOS2 enzyme activity, we examined protein levels by Western blot and cellular NO release by assaying culture supernatant nitrite levels after 


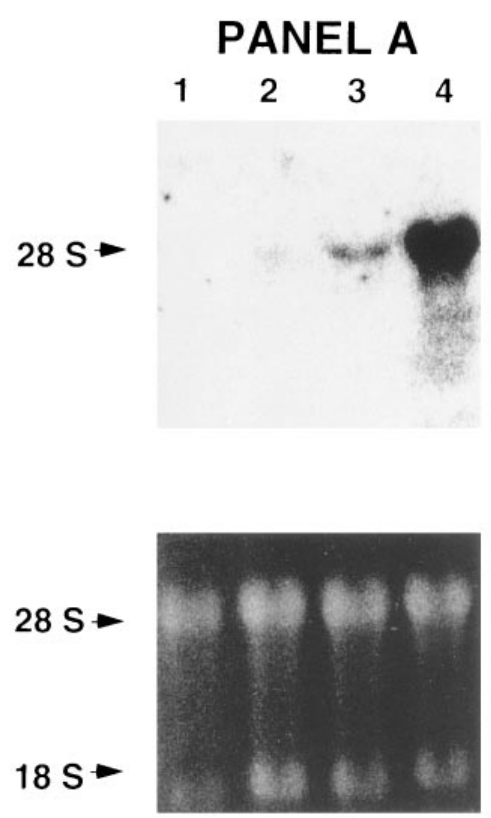

4

PANEL B

$\begin{array}{llll}1 & 2 & 3 & 4\end{array}$
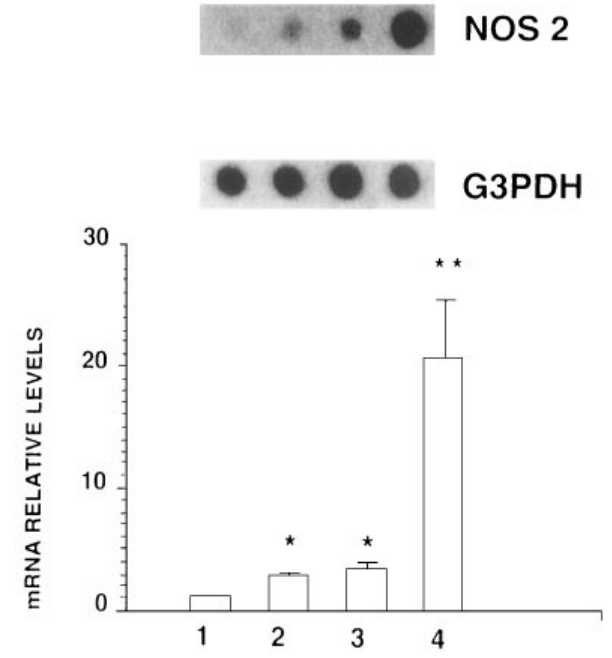

Figure 3. NOS2 mRNA levels in HepG2 and 2.2.15 hepatoma cell lines after $12 \mathrm{~h}$ stimulation with CM (Northern blot, PANEL A; dot blot, PANEL B, top). Lane 1, Resting HepG2 cells. Lane 2, CM-stimulated HepG2 cells. Lane 3, Resting 2.2.15 cells. Lane 4, CM-stimulated 2.2.15 cells. Maximal induction of NOS2 mRNA levels is observed in lane 4 , corresponding to CMstimulated 2.2 .15 cells. $B$, middle, shows that probing for G3PDH demonstrated relatively equal loading of RNA samples in all lanes. B, bottom, Relative levels for NOS2 mRNA as assessed by scanning densitometry. An approximately threefold induction of NOS2 mRNA levels is observed in CMstimulated HepG 2 cells $(P<0.05$ vs. resting HepG2 cells). However, induction is still higher in CM-stimulated 2.2.15 cells ( $~ 21$-fold induction, $P<0.01$ vs. resting HepG2 cells). Northern and dot blot shown are representative of three separate experiments performed at different times using RNA isolated from different cell samples, and each study yielded similar results. $* P<$ 0.05 vs. resting HepG 2 cells. $* * P<0.01$ vs. resting HepG2 cells.
A

B

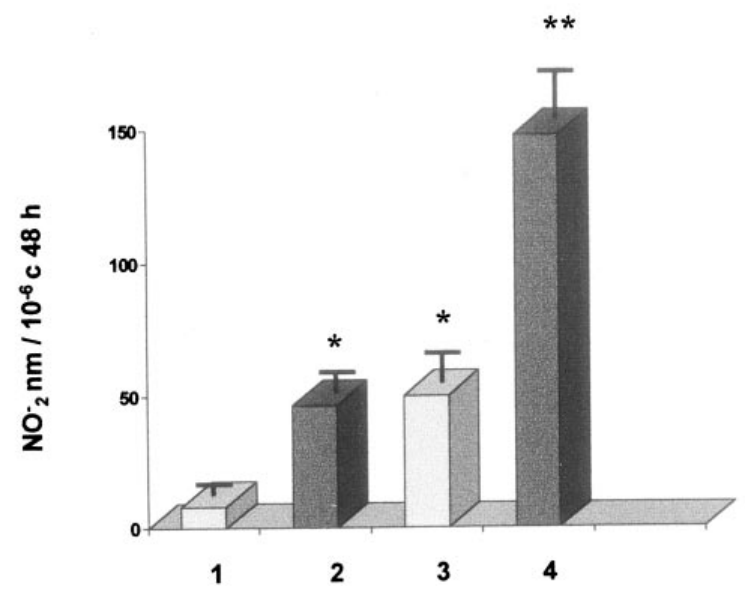

Figure 4. Increase in NOS2 protein expression and enzymatic activity in HepG2 and 2.2.15 hepatoma cell line supernatants after $48 \mathrm{~h}$ stimulation with CM. Lane $C$, Positive control, LPS-treated mouse macrophage lysate. Lane 1, Resting HepG2 cells. Lane 2, CM-stimulated HepG2 cells. Lane 3, Resting 2.2.15 cells. Lane 4, CM-stimulated 2.2.15 cells. NOS2 protein levels $(A)$ as well as NO synthesis $(B)$ were
CM stimulation of both untransfected and HBV-stably transfected HepG2 cells (2.2.15 cells) (Fig. 4). NO synthesis was greater in CM-stimulated (an approximately fivefold induction, $P<0.05$ ) than in resting HepG2 cells, but it was quite similar to that observed in resting 2.2.15 cells. However, the maximal NO production was found in 2.2.15 cells after $48 \mathrm{~h}$ of stimulation with a $\mathrm{CM}$ (an $\sim 25$-fold induction, $P<0.01$ vs. resting HepG2 cells) (Fig. 4 B). Interestingly, NOS2 enzyme activity correlated well with NOS2 protein expression, as demonstrated by immunoblot experiments performed in parallel in these same cells (Fig. $4 A$ ).

Since the 2.2.15 cell line is a subclone of HepG2, the differences observed between them on NOS2 gene expression could be due to undefined clonal differences rather than to the presence of HBV. To elucidate this issue, we performed transient transfection experiments on distinct cell lines, HepG2, Hep3B, and CCL13 cells, using a plasmid containing the whole genome of $\mathrm{HBV}$, termed $\mathrm{pHBV}$, as well as the plasmid pSV-X, which contains the entire open reading frame of the HBV $\mathrm{X}$ gene. Three irrelevant plasmids, designated psP65, psV-H, and $\mathrm{psV}$ $\beta \mathrm{Gal}$, were used as controls. After transfection, NOS 2 mRNA expression in resting transfected HepG2 cells was analyzed by

greater in lane 2 (an approximately fivefold induction, $P<0.05$ ) than lane 1 , but quite similar to lane 3 . However, the maximal NO production (145.3 $\pm 15.6 \mathrm{nmol} \mathrm{NO}_{2}{ }^{-} / 10^{6}$ cells) was found in $\mathrm{CM}$-stimulated 2.2.15 cells ( $B$, lane 4$)$, and correlated well with NOS2 protein expression, as demonstrated by immunoblot experiments performed in parallel in these same cells $(A)$. Western blot shown is representative of three separate experiments, and each study yielded similar results. Values for nitrite measurements are expressed as mean \pm SEM for three separate experiments carried out in duplicate. ${ }^{*} P<0.05$ vs. resting HepG2 cells. ${ }^{* *} P<0.01$ vs. resting HepG2 cells. 
A
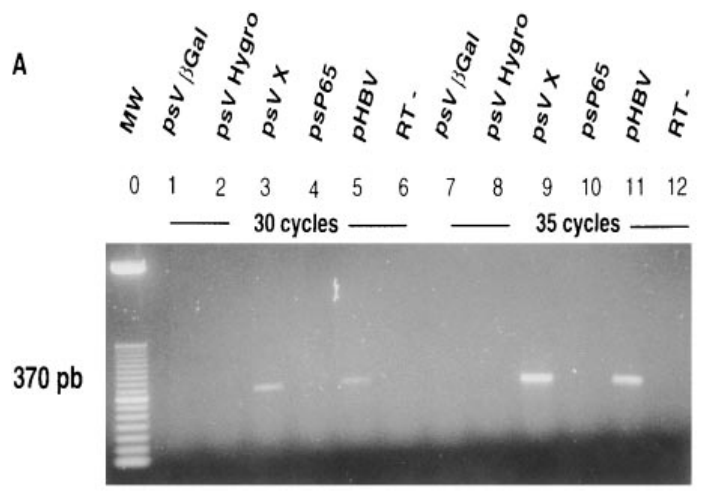

NOS 2

B

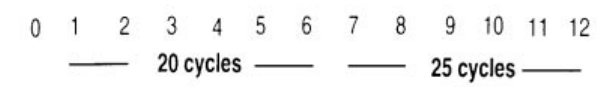

$838 \mathrm{pb}$

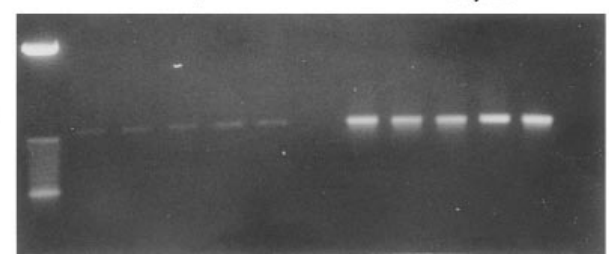

$\beta$ Actin

Figure 5. RT-PCR for human NOS2 mRNA in transiently transfected HepG2 cells demonstrating the expected 370-bp product after 30 cycles of amplification $(A)$. Lane 1 , Representative $\beta$-galactosidase gene-transfected resting cells ( $p s V \beta G a l)$. Lane 2, Representative hygromicine gene-transfected resting cells ( $p s V$ Hygro). Lane 3, Representative HBV X gene-transfected resting cells $(p s V X)$. Lane 4, Representative psP65 plasmid-transfected resting cells. Lane 5, Representative HBV genome-transfected resting cells $(p H B V)$. Lane 6 , Negative control, as a PCR reaction without reverse transcriptase $(R T-)$. After 35 cycles of amplification (Lanes 7-12), a stronger amplification signal was observed only in HBV X gene-transfected resting HepG2 cells (lane 9) and in HBV genome-transfected resting HepG2 cells (lane 11). In $B$, after 25 cycles of amplification, the 838-bp PCR product corresponding to $\beta$-actin showed a relatively equal amount of RNA per lane.

reverse transcription (RT) PCR. As shown in Fig. 5, the expected 370-bp product was detected in HepG2 cells transiently transfected with psV-X and pHBV (lanes 3, 5, 9, and 11), whereas the specific band was absent in cells transfected with control plasmids in both 30 and 35 cycles of amplification. As a positive control, application of RT-PCR in RNA samples from 2.2.15 cells demonstrated the predicted 370-bp product (data not shown). Sequencing of this PCR product confirmed its identity as NOS2. The 838-bp amplification product corresponding to $\beta$-actin, which was detected after 20 cycles of amplification reactions, showed a relatively equal amount of RNA per lane (Fig. 5 B). Finally, and as expected, experiments performed on Hep3B and CCL13 cells yielded similar results (data not shown).

\section{Discussion}

The most striking finding of this study was that hepatotropic viral infection plays a relevant role in the hepatocellular NOS2 upregulation, either independently or in addition to that exerted by locally released cytokines from activated immune cells that infiltrate the liver tissue of CVH patients $(32,33)$. In this sense, our data herein clearly demonstrate that although HBV itself was able to induce the NOS2 gene expression, this effect was enhanced markedly by proinflammatory cytokines. This apparent cytokine-mediated synergistic effect on hepatocellular NOS2 gene expression in vitro could also be operative in vivo since an enhanced intrahepatic expression of some cytokines, such as TNF- $\alpha$ (20) and IFN- $\gamma$ (21), in CVH has been demonstrated recently. In our experiments on cultured hepatoma cells stimulated with a CM, when NOS2 mRNA levels were quantitated by radioanalytic scanning, CM-stimulated untransfected HepG2 cells and resting HBV-transfected HepG2 cells accounted for a small percentage of maximal NOS2 mRNA expression shown by CM-stimulated HBV-transfected HepG2 cells. These data suggest that proinflammatory cytokines and HBV are truly synergistic for NOS2 expression, because the magnitude of the NOS2 mRNA levels found in CMstimulated HBV-transfected cells was greater than the sum of the separate conditions. Nevertheless, the precise molecular basis for this synergy remains to be defined.

Although distinct viruses such as EBV (34), HIV-1 (35), and Coxsackie virus B3 (36) have been demonstrated to be able to induce NOS2 expression, to our knowledge, in this work we provide the first evidence that the $X$ gene product of HBV alone can upregulate the NOS2 gene expression in cultured human hepatocyte-derived cells. Furthermore, the presence of an enhanced NOS2 expression in hepatocytes from patients with $\mathrm{CAHB}$, without relationship to the degree of hepatic inflammation, strongly supports the assumption that a similar HBx-mediated effect on NOS2 gene expression could be fully operative in human hepatocytes during in vivoacquired HBV infection. According to our immunohistochemical and in situ hybridization findings from patients with CAHC, a similar situation in HCV-infected hepatocytes may occur. Supporting this latter assumption, recent data from Mihm et al. (37) demonstrated that NOS2 transcript expression was increased in the liver tissue of chronically HCVinfected patients, and that it was found to be positively correlated with hepatic HCV RNA content in these patients. All these findings suggest that intrahepatic viral load appears to be a key point influencing the hepatocellular NOS2 expression during both chronic HBV and HCV infections.

De Vera et al. (38) demonstrated that the human NOS2 gene is regulated transcriptionally by proinflammatory cytokines through responsive elements located upstream of the proximal 5' flanking region. However, they showed that the proximal $5^{\prime}$ flanking region of human NOS2 gene contains multiple putative cytokine-responsive elements, such as nuclear factor $\kappa \mathrm{B}$ and IFN- $\gamma$-responsive elements. It is well known that $\mathrm{HBV}$ is able to induce the expression of viral and cellular genes $(39,40)$, and that this effect is mediated, at least in part, by $\mathrm{HBx}$, which transactivates gene promoters containing multiple sequence motifs, including nuclear factor $\kappa \mathrm{B}$ binding sites $(41,42)$. The presence of a number of these cis-acting elements within the human NOS2 gene promoter makes it conceivable that hepatocellular NOS2 gene expression may also be transcriptionally upregulated by HBx. However, NOS2 expression is known to be regulated on several levels, including mRNA stability, protein degradation, and enzyme activity (43). Although we have obtained evidence that the NOS2 gene promoter activity is induced markedly in transiently $\mathrm{HBV} \mathrm{X}$ gene-transfected cells, supporting a virus-induced NOS2 gene 
upregulation at the transcriptional level (our unpublished data), the mild discrepancy between NOS2 mRNA and protein levels observed in cytokine-stimulated HepG2 cells suggests that a posttranscriptional regulation may also exist. Nevertheless, further studies are needed to clarify more accurately the mechanisms by which HBV induces NOS 2 gene expression in human hepatocytes. These studies are currently ongoing in our laboratory.

$\mathrm{NO}$ is an important effector molecule involved in a wide variety of physiological processes, such as neurotransmission, vasodilation, and cytotoxicity (44). Recent studies have shown that NO is also implicated in other activities, such as growth inhibition of DNA viruses $(45,46)$, as a second messenger mediating endothelial cell growth (47), and as a potent radical molecule contributing to DNA damage and carcinogenesis (48, 49). Based on our findings from patients with $\mathrm{CVH}$, the increased hepatocellular NOS2 expression could be part of a nonspecific host response to viral infection inhibiting its replication. This antiviral effect of NO would explain, at least in part, the increase in viral titers observed when corticosteroids, which are NOS2 inhibitors (50), are used in patients with CVH (51).

It has been described that NO promotes angiogenesis in vivo (52), and we have demonstrated recently the existence of an active process of angiogenesis in portal tracts from patients with CVH (19). The present data lead us to hypothesize that a link may exist between enhanced hepatocellular NO production and portal angiogenesis, but the possible role played by NO mediating intrahepatic angiogenesis remains to be elucidated.

A major epidemiological association between either chronic HBV or HCV infections and hepatocellular carcinoma (HCC) is evident $(53,54)$. However, the underlying mechanisms that lead to the development of HCC are still not entirely understood. Although integration of HBV DNA sequences into the liver cell genome could activate cellular protooncogenes, it is very infrequent and hence does not explain the majority of $\mathrm{HBV}$-induced HCCs (55). It is well known that high levels of NO can cause deamination of DNA bases, leading to DNA damage as well as mutation in human cells $(48,49)$, and it has been demonstrated more recently that $\mathrm{NO}$ is able to induce functional modifications of p53 tumorsuppressor protein (56), increasing the risk of malignant cell transformation. The first experimental evidence of a link between hepadnavirus infection and NO production came from several reports of Liu et al. $(57,58)$, who showed that woodchucks chronically infected with woodchuck hepatitis virus, which is a member of the hepadnavirus family to which HBV belongs, exhibited a significant increase in NO production in vivo and endogenous formation of $\mathrm{N}$-nitroso carcinogenic compounds. More recently, the same authors demonstrated that woodchuck HBsAg alone was sufficient to induce high levels of NO synthesis in cultured hepatocytes (59). In humans, an alternative explanation may be that the unregulated expression of $\mathrm{HBx}$ contributes to the malignant transformation of the infected hepatocytes, either through its transcriptional transactivating properties $(60,61)$ or by inactivating the p53 tumorsuppressor gene product $(62,63)$. Interestingly, overexpression of NOS2 induces the hepatocellular accumulation of p53 and subsequent downregulation of NO synthesis through p53mediated inhibition of NOS2 promoter (64). Therefore, a possible pathogenic mechanism of liver cancer might be that the disruption of p53 activity either by mutations, as observed frequently in HCC (65), or by interactions with viral proteins, such as HBx (66), would produce a loss in p53-mediated regulation of NOS2 activity. In addition, the HBx-mediated upregulation of human hepatocyte NOS2 gene could generate a long-term overproduction of NO in liver cells, resulting in an increase in NO-related DNA damage leading to the development of neoplastic cell growth, thus providing a mechanism by which chronic HBV infection increases the risk of liver cancer.

In conclusion, we have demonstrated that hepatotropic viral infections induce NOS2 gene upregulation in human hepatocytes, suggesting that the increased intrahepatic NO production could play an important functional role influencing the natural history of virus-induced chronic hepatitis. Additionally, although the intrahepatic expression level of NOS2 was significantly lower in both alcoholic liver disease and nonimmune-mediated cholestasis than in $\mathrm{CVH}$, further studies are warranted to test whether this low level of hepatocellular NOS2 expression could have significance for the pathobiology of these processes.

\section{Acknowledgments}

The liver pathological analysis of Dr. Asunción García-Sánchez is gratefully acknowledged. We wish to thank Dr. Massimo Levrero and Dr. Francisco Sánchez-Madrid for critical readings of the manuscript and for helpful suggestions. We are also indebted to Brenda Ashley for her English language assistance, and Rocha Barroso for preparing the manuscript.

This work has been supported by grants to R. Moreno-Otero (Fondo de Investigacion Sanitaria [FIS] 95/0264) and to M. LópezCabrera (FIS 95/0208) from Instituto Nacional de la Salud.

\section{References}

1. Moncada, S., R.M.J. Palmer, and E.A. Higgs. 1989. Biosynthesis of nitric oxide from L-arginine: a pathway for the regulation of cell function and communication. Biochem. Pharmacol. 38:1709-1715.

2. Moncada, S., R.M.J. Palmer, and E.A. Higgs. 1991. Nitric oxide: physiology, pathophysiology, and pharmacology. Pharmacol. Rev. 43:109-142.

3. Nathan, C., and Q.W. Xie. 1994. Nitric oxide synthases: roles, tolls, and controls. Cell. 78:915-918.

4. Bredt, D.S., and S.H. Snyder. 1990. Isolation of nitric oxide synthase, a calmodulin-requiring enzyme. Proc. Natl. Acad. Sci. USA. 87:682-685.

5. Janssens, S.P., A. Shimouchi, T. Quertermous, D.B. Bloch, and K.D. Bloch. 1992. Cloning and expression of a cDNA encoding human endotheliumderived relaxing factor/nitric oxide synthase. J. Biol. Chem. 267:14519-14522 (erratum, 267:22964).

6. Xie, Q.W., H.J. Cho, J. Calaycay, R.A. Mumford, K.M. Swiderek, T.D. Lee, A. Ding, T. Troso, and C. Nathan. 1992. Cloning and characterization of inducible nitric oxide from mouse macrophages. Science. 256:225-228.

7. Geller, D.A., C.J. Lowestein, R.A. Shapiro, A.K. Nussler, M. Di Silvio, S.C. Wang, D.K. Nakayama, R.L. Simmons, S.H. Snyder, and T.R. Billiar. 1993 Molecular cloning and expression of inducible nitric oxide synthase from human hepatocytes. Proc. Natl. Acad. Sci. USA. 90:3491-3495.

8. Nussler, A.K., M. Di Silvio, T.R. Billiar, R.A. Hoffman, D.A. Geller, R. Selby, J. Madariaga, and R.L. Simmons. 1992. Stimulation of the nitric oxide synthase pathway in human hepatocytes by cytokines and endotoxin. $J$. Exp. Med. 176:261-264.

9. Geller, D.A., A.K. Nussler, M. Di Silvio, C.J. Lowestein, R.A. Shapiro, S.C. Wang, R.L. Simmons, and T.R. Billiar. 1993. Cytokines, endotoxin, and glucocorticoids regulate the expression of inducible nitric oxide synthase in hepatocytes. Proc. Natl. Acad. Sci. USA. 90:522-526.

10. Moncada, S. 1992. The 1991 Ulf von Euler Lecture. The L-arginine:nitric oxide pathway. Acta Physiol. Scand. 145:201-227.

11. MacMicking, J.D., D.O. Willenborg, M.J. Weidemann, K.A. Rockett, and W.B. Cowden. 1992. Elevated secretion of reactive nitrogen and oxygen intermediates by inflammatory leukocytes in hyperacute experimental autoimmune encephalomyelitis: enhancement by the soluble products of encephalitogenic T cells. J. Exp. Med. 176:303-307.

12. Weinberg, J.B., D.L. Granger, D.S. Pisetsky, M.F. Seldin, M.A. Misukonis, S.N. Mason, A.M. Pippen, P. Ruiz, E.R. Wood, and G.S. Gilkeson. 1994. 
The role of nitric oxide in the pathogenesis of spontaneous murine autoimmune disease: increased nitric oxide production and nitric oxide synthase expression in MRL-lpr/lpr mice, and reduction of spontaneous glomerulonephritis and arthritis by orally administered $\mathrm{N}^{\mathrm{G}}$-monomethyl-L-arginine. J. Exp. Med. 179: 651-660.

13. Sakurai, H., H. Kohsaka, M.F. Liu, H. Higashiyama, Y. Hirata, K. Kanno, I. Saito, and N. Miyasaka. 1995. Nitric oxide production and inducible nitric oxide synthase expression in inflammatory arthritides. J. Clin. Invest. 96: 2357-2363.

14. St. Clair, E.W., W.E. Wilkinson, T. Lang, L. Sanders, M.A. Misukonis, G.S. Gilkenson, D.S. Pisetsky, D.L. Granger, and J.B. Weinberg. 1996. Increased expression of blood mononuclear cell nitric oxide synthase type 2 in rheumatoid arthritis patients. J. Exp. Med. 184:1173-1178.

15. McInnes, I.B., B.P. Leung, M. Field, X.Q. Wei, F.P. Huang, R.D. Sturrock, A. Kinninmonth, J. Weidner, R. Mumford, and F.Y. Liew. 1996. Production of nitric oxide in the synovial membrane of rheumatoid and osteoarthritis patients. J. Exp. Med. 184:1519-1524.

16. Vodovotz, Y., M.S. Lucia, K.C. Flanders, L. Chesler, Q.W. Xie, T.W. Smith, J. Weidner, R. Mumford, R. Webber, C. Nathan, et al. 1996. Inducible nitric oxide synthase in tangle-bearing neurons of patients with Alzheimer's disease. J. Exp. Med. 184:1425-1433.

17. Moreno-Otero, R., L. García-Buey, F.G. Mateos, and C. GarcíaMonzón. 1996. Pathogenesis of chronic viral hepatitis: lessons from immunohistochemistry. Viral Hepatitis Rev. 2:61-79.

18. García-Monzón, C., L. García-Buey, A. García-Sánchez, J.M. Pajares, and R. Moreno-Otero. 1993. Down-regulation of intercellular adhesion molecule 1 on hepatocytes in viral chronic hepatitis treated with interferon alpha-2b. Gastroenterology. 105:462-469.

19. García-Monzón, C., F. Sánchez-Madrid, L. García-Buey, A. GarcíaArroyo, A. García-Sánchez, and R. Moreno-Otero. 1995. Vascular adhesion molecule expression in viral chronic hepatitis: evidence of neoangiogenesis in portal tracts. Gastroenterology. 108:231-241.

20. González-Amaro, R., C. García-Monzón, L. García-Buey, R. MorenoOtero, J.L. Alonso, E. Yagüe, J.P. Pivel, M. López-Cabrera, E. FernándezRuiz, and F. Sánchez-Madrid. 1994. Induction of tumor necrosis factor $\alpha$ production by human hepatocytes in chronic viral hepatitis. J. Exp. Med. 179:841-848.

21. Mihm, S., A. Hutschenreiter, A. Fayyazi, S. Pingel, and G. Ramadori. 1996. High inflammatory activity is associated with an increased amount of IFN- $\gamma$ transcripts in peripheral blood cells of patients with chronic hepatitis $\mathrm{C}$ virus infection. Med. Microbiol. Immunol. 185:95-102.

22. Geller, D.A., M.E. de Vera, D.A. Russell, R.A. Shapiro, A.K. Nussler, R.L. Simmons, and T.R. Billiar. 1995. A central role for IL-1 $\beta$ in the in vitro and in vivo regulation of hepatic inducible nitric oxide synthase. IL- $1 \beta$ induces hepatic nitric oxide synthesis. J. Immunol. 155:4890-4898.

23. Hu, K.Q., J.M. Vierling, and A. Siddiqui. 1990. Trans-activation of HLA-DR gene by hepatitis B virus X gene product. Proc. Natl. Acad. Sci. USA. 87:7140-7144.

24. Hu, K.Q., C.H. Yu, and J.M. Vierling. 1992. Up-regulation of intercellular adhesion molecule 1 transcription by hepatitis B virus X protein. Proc. Natl. Acad. Sci. USA. 89:11441-11445.

25. 1977. Acute and chronic hepatitis revisited. Review by an international group. Lancet. 2:914-919.

26. Muñoz-Gómez, R., C. García-Monzón, L. García-Buey, O. Lo Iacono, M.J. Borque, A. García-Sánchez, J.M. Pajares, and R. Moreno-Otero. 1996. Hepatitis $\mathrm{C}$ virus infection in Spanish volunteer blood donors: HCV RNA analysis and liver disease. Eur. J. Gastroenterol. Hepatol. 8:273-277.

27. Knodell, R.G., K.G. Ishack, W.C. Black, T.S. Chen, R. Craig, N. Kaplowitz, T.W. Kierman, and J. Wollman. 1981. Formulation and application of a numerical scoring system for assessing histological activity in asymptomatic chronic active hepatitis. Hepatology. 5:431-435.

28. Amin, A.R., P.E. Di Cesare, P. Vyas, M. Attur, E. Tzeng, T.R. Billiar, S.A. Stuchin, and S.B. Abramson. 1995. The expression and regulation of nitric oxide synthase in human osteoarthritis-affected chondrocytes: evidence for upregulated neuronal nitric oxide synthase. J. Exp. Med. 182:2097-2102.

29. Wilkinson, D.G., and M.A. Nieto. 1993. Analysis of gene expression by in situ hybridization to tissue sections and in whole mount. Methods Enzymol. 225:361-368.

30. Sells, M.A., M.L. Chen, and G. Acs. 1987. Production of hepatitis B virus particles in HepG2 cells transfected with cloned hepatitis B virus DNA. Proc. Natl. Acad. Sci. USA. 84:1005-1009.

31. Green, L.C., D.A. Wagner, J. Glogowsky, P.L. Skipper, J.S. Wishnok, and S.R. Tannenbaum. 1982. Analysis of nitrate, nitrite and $\left[{ }^{15} \mathrm{~N}\right]$ nitrate in biological fluids. Anal. Biochem. 126:131-138.

32. García-Monzón, C., R. Moreno-Otero, J.M. Pajares, A. García-Sánchez, M. López-Botet, M.O. de Landázuri, and F. Sánchez-Madrid. 1990. Expression of a novel activation antigen on intrahepatic CD8 $+\mathrm{T}$ lymphocytes in viral chronic active hepatitis. Gastroenterology. 98:1029-1035.

33. Hata, K., D.H. Van Thiel, R.B. Herberman, and T.H. Whiteside. 1992. Phenotypic and functional characteristics of lymphocytes isolated from liver biopsy specimens from patients with active liver disease. Hepatology. 15:816-823.

34. Mannick, J.B., K. Asano, K. Izumi, E. Kieff, and J.S. Stamler. 1995. Nitric oxide produced by human B lymphocytes inhibits apoptosis and Epstein-
Barr virus reactivation. Cell. 79:1137-1146.

35. Adamson, D.C., B. Wildemann, M. Sasaki, J.D. Glass, J.C. McArthur V.I. Christov, T.M. Dawson, and V.L. Dawson. 1996. Immunologic NO synthase: elevation in severe AIDS dementia and induction by HIV-1 gp41. Science. 274:1917-1921.

36. Lowestein, C.J., S.L. Hill, A. Lafond-Walker, J. Wu, G. Allen, M. Landavere, N.R. Rose, and A. Herskowitz. 1996. Nitric oxide inhibits viral replication in murine myocarditis. J. Clin. Invest. 97:1837-1843.

37. Mihm, S., A. Fayyazi, and G. Ramadori. 1997. Hepatic expression of inducible nitric oxide synthase transcripts in chronic hepatitis $\mathrm{C}$ virus infection: relation to hepatic viral load and liver injury. Hepatology. 26:451-458.

38. De Vera, M.E., R.A. Shapiro, A.K. Nussler, J.S. Mudgett, R.L. Simmons, S.M. Morris, T.R. Billiar, and D.A. Geller. 1996. Transcriptional regulation of human inducible nitric oxide synthase (NOS2) gene by cytokines: initial analysis of the human NOS2 promoter. Proc. Natl. Acad. Sci. USA. 93:10541059.

39. Twu, J.S., K. Chu, and W.S. Robinson. 1989. Hepatitis B virus X gene activates $\mathrm{\kappa B}$-like enhancer sequences in the long terminal repeat of human immunodeficiency virus 1. Proc. Natl. Acad. Sci. USA. 86:5168-5172.

40. Yoo, Y.D., H. Ueda, K. Park, K.C. Flanders, Y.I. Lee, G. Jay, and S.J. Kim. 1996. Regulation of transforming growth factor- $\beta 1$ expression by the hepatitis B virus (HBV) X transactivator: role in $\mathrm{HBV}$ pathogenesis. J. Clin. Invest. 97:388-395.

41. Kekulé, A.S., U. Lauer, L. Weiss, B. Luber, and P.S. Hofschneider. 1993. Hepatitis B virus transactivator HBx uses a tumour promoter signalling pathway. Nature. 361:742-745.

42. Chirillo, P., M. Falco, P.L. Puri, M. Artini, C. Balsano, M. Levrero, and G. Natoli. 1996. Hepatitis B virus $\mathrm{pX}$ activates NF-кB-dependent transcription through a raf-independent pathway. J. Virol. 70:641-646.

43. Lyons, C.R. 1995. The role of nitric oxide in inflammation. Adv. Immunol. 60:323-371.

44. Moncada, S., and A. Higgs. 1993. The L-arginine-nitric oxide pathway. N. Engl. J. Med. 329:2002-2012.

45. Karupiah, G., Q.W. Xie, R.M. Buller, C. Nathan, C. Duart, and J.D. MacMicking. 1993. Inhibition of viral replication by interferon-gamma-induced nitric oxide synthase. Science. 261:1445-1448.

46. Croen, K.D. 1993. Evidence for antiviral effect of nitric oxide. Inhibition of herpes simplex virus type 1 replication. J. Clin. Invest. 91:2446-2452.

47. Ziche, M., L. Morbidelli, E. Masini, H.J. Granger, P. Geppetti, and F. Ledda. 1993. Nitric oxide promotes DNA synthesis and cyclic GMP formation in endothelial cells from postcapillary venules. Biochem. Biophys. Res. Commun. 192:1198-1203.

48. Wink, D.A., K.S. Kasprzak, C.M. Maragos, R.K. Elespuru, M. Misra, T.M. Dunams, T.A. Cebula, W.H. Koch, A.W. Andrews, J.S. Allen, and L.K. Keefer. 1991. DNA deaminating ability and genotoxicity of nitric oxide and its progenitors. Science. 254:1001-1003.

49. Nguyen, T., D. Brunson, C.L. Crespi, B.W. Penman, J.S. Wishnok, and S.R. Tannenbaum. 1992. DNA damage and mutation in human cells exposed to nitric oxide in vitro. Proc. Natl. Acad. Sci. USA. 89:3030-3034.

50. Radomski, M.W., R.M.J. Palmer, and S. Moncada. 1990. Glucocorticoids inhibit the expression of an inducible, but not the constitutive, nitric oxide synthase in vascular endothelial cells. Proc. Natl. Acad. Sci. USA. 87:1004310047.

51. Scullard, G.H., C.I. Smith, T.C. Merigan, W.S. Robinson, and P.B. Gregory. 1981. Effects of immunosuppressive therapy on viral markers in chronic active hepatitis B. Gastroenterology. 81:987-991.

52. Ziche, M., L. Morbidelli, E. Masini, S. Amerini, H.J. Granger, C.A. Maggi, P. Geppetti, and F. Ledda. 1994. Nitric oxide mediates angiogenesis in vivo and endothelial cell growth and migration in vitro promoted by substance P. J. Clin. Invest. 94:2036-2044.

53. Blumberg, B.S., and W.T. London. 1981. Hepatitis B virus and the prevention of primary hepatocellular carcinoma. N. Engl. J. Med. 304:782-784.

54. Bruix, J., J.M. Barrera, X. Calvet, G. Ercilla, J. Costa, J.M. SánchezTapias, M. Ventura, M. Vall, M. Bruguera, C. Bru, et al. 1989. Prevalence of antibodies to hepatitis $\mathrm{C}$ virus in Spanish patients with hepatocellular carcinoma and hepatic cirrhosis. Lancet. 2:1004-1006.

55. Chisari, F.V., K. Klopchin, T. Moriyama, C. Pasquinelli, H.A. Dunsford, S. Sell, C.A. Pinkert, R.L. Brinster, and R.D. Palmiter. 1989. Molecular pathogenesis of hepatocellular carcinoma in hepatitis B virus transgenic mice. Cell. 59:1145-1156.

56. Calmels, S., P. Hainaut, and H. Ohshima. 1997. Nitric oxide induces conformational and functional modifications of wild-type p53 tumor suppressor protein. Cancer Res. 57:3365-3369.

57. Liu, R.H., B. Baldwin, B.C. Tennant, and J.H. Hotchkiss. 1991. Elevated formation of nitrate and $N$-nitrosodimethylamine in woodchucks ( $\mathrm{Mar}$ mota monax) associated with chronic woodchuck hepatitis virus infection. Cancer Res. 51:3925-3929.

58. Liu, R.H., J.R. Jacob, B.C. Tennant, and J.H. Hotchkiss. 1992. Nitrite and nitrosamine synthesis by hepatocytes isolated from normal woodchucks (Marmota monax) and woodchucks chronically infected with woodchuck hepatitis virus. Cancer Res. 52:4139-4143.

59. Liu, R.H., J.R. Jacob, J.H. Hotchkiss, P.J. Cote, J.L. Gerin, and B.C. 
Tennant. 1994. Woodchuck hepatitis virus surface antigen induces nitric oxide synthesis in hepatocytes: possible role in hepatocarcinogenesis. Carcinogenesis. 15:2875-2877.

60. Aufiero, B., and R.J. Schneider. 1990. The hepatitis B virus X gene product transactivates both RNA polymerases II and III promoters. EMBO (Eur. Mol. Biol. Organ.) J. 9:497-504

61. Benedict Yen, T.S. 1996. Hepadnaviral X protein: review of recent progress. J. Biomed. Sci. 3:20-30.

62. Wang, X.W., M.K. Gibson, W. Vermeulen, H. Yeh, K. Forrester, H.-W. Stürzbecher, J.H.J. Hoeijmakers, and C.C. Harris. 1995. Abrogation of p53induced apoptosis by the hepatitis B virus X gene. Cancer Res. 55:6012-6016.

63. Ueda, H., S.J. Ullrich, J.D. Gangemi, C.A. Kappel, L. Ngo, M.A. Feitelson, and G. Jay. 1995. Functional inactivation but not structural mutation of p53 causes liver cancer. Nat. Gen. 9:41-47.

64. Forrester, K., S. Ambs, S.E. Lupold, R.B. Kapust, E.A. Spillare, W.C Weinberg, E. Felley-Bosco, X.W. Wang, D.A. Geller, E. Tzeng, et al. 1996. Nitric oxide-induced p53 accumulation and regulation of inducible nitric oxide synthase expression by wild-type p53. Proc. Natl. Acad. Sci. USA. 93:2442-2447.

65. Greenblatt, M.S., W.P. Bennett, M. Hollstein, and C.C. Harris. 1994. Mutations in the p53 tumor suppressor gene: clues to cancer etiology and molecular pathogenesis. Cancer Res. 54:4855-4878.

66. Truant, R., J. Antunovic, J. Greenblatt, C. Prives, and J.A. Cromlish. 1995. Direct interaction of the hepatitis B virus HBx protein with p53 leads to inhibition by HBx of p53 response element-directed transactivation. J. Virol. 69:1851-1859. 